\title{
Does the glycogen synthase $(E C$ 2.4.1.21) of brown adipose tissue play a regulatory role in glucose homeostasis?
}

\author{
BY ZECHARIA MADAR AND AYALAH HAREL \\ Department of Biochemistry and Human Nutrition, Faculty of Agriculture, The Hebrew University \\ of Jerusalem, PO Box 12, Rehovot 76100, Israel
}

(Received 6 February 1990 - Accepted 21 September 1990)

\begin{abstract}
Glycogen synthase (GS) activity was characterized in rat brown adipose tissue (BAT) and the activity was found to be much higher than that in white adipose tissue. Prolonged starvation had no effect on the active form of GS, as found in the liver and muscle. The GS activity was similar in BAT of rats housed in an animal room $\left(21 \pm 1^{\circ}\right)$ whether they were fed on high-carbohydrate, high-fat, or stock diets. Acclimatizatioin of rats to cold $\left(4 \pm 1^{\circ}\right)$ for 2 weeks significantly increased GS activity. This increase in the cold was fivefold greater when rats were fed on high-carbohydrate diets than in control rats at room temperature fed on an identical diet. The increase was accompanied by a large accumulation of glycogen in BAT. It was concluded that GS may play an important role in BAT and may contribute to the control of blood glucose in a cold environment. Its relevance to thermogenesis requires further elucidation.
\end{abstract}

Fasting: High-carbohydrate diet: High-fat diet: Glycogen synthase

The control of blood glucose levels depends on the rates of glucose production and utilization (Cooney \& Newsholme, 1984). In addition to the tissues shown to be important in this process, as they convert glucose to the storage fuels such as triacylglycerol and glycogen, brown adipose tissue (BAT) was also found to possess high rates of lipogenesis, possibly from glucose (Ferre et al. 1986). BAT was also shown to have a high capacity for glucose utilization. These capabilities raise the possibility that this tissue uses not only triacylglycerol (a proven fact), but also glucose for thermogenesis (McCormack, 1982; McCormack et al. 1986; Isler et al. 1987). Hence, BAT could play an important role in the removal of glucose following carbohydrate loading (Trayhurn, 1979). This in turn could result in the control of blood glucose concentration particularly in cold-acclimatized rats. If so, then the induction of the glucose utilization process would require stimulation of the enzymes in BAT involved in this pathway. Several enzymes have been measured in this tissue (Cooney et al. 1981; Young et al. 1984) and found to be inducible. Glycolytic enzymes (hexokinase ( $E C$ 2.7.1.1) and 6-phosphofructokinase ( $E C$ 2.7.1.11)) were activated when a high rate of lipogenesis was observed (Cooney \& Newsholme, 1982). In fed rats, the increased BAT lipogenesis observed in vivo in response to glucose was associated with activation of pyruvate dehydrogenase $(E C 1.2 .2 .2 ., 1.2 .4 .1 ; \mathrm{PDH})$ (Denton et al. 1984). This enzyme was also activated in starved rats fed on glucose. Although previous studies have shown that glucose in BAT was directed into the lipogenic process (Denton et al. 1984; Cooney \& Newsholme, 1984), the possibility exists that glucose will also be deposited as glycogen.

If we follow the pathway of glycogen deposition from a reservoir of glucose as fuel for thermogenesis and also as a lipogenic precursor, we can assume that the glycogen synthase (EC 2.4.1.21; GS) enzyme contributes to the pathway of glycogen synthesis. GS is an interconvertible enzyme that exists in active and inactive forms depending on the 
physiological status of the animals. The effect of prolonged starvation and exposure to cold on GS in BAT has yet to be studied.

To the best of our knowledge, little information is available regarding GS activity in BAT, when compared with liver, muscle and white adipose tissue. However, one report described an increase in GS activity in the BAT of cold-acclimatized rats (Gibbins \& Denton, 1986). The object of the present study was to demonstrate in greater detail such GS activity in BAT, and to clarify the time-course of GS activity after different periods of starvation. In addition, the present work was aimed at determining whether feeding highcarbohydrate (HC) or high-fat (HF) diets to cold-acclimatized rats affects GS activity.

\section{MATERIALS AND METHODS}

\section{Experimental protocol}

Male Sabra rats $(80-100 \mathrm{~g})$ of the Hebrew University strain were housed individually in wire-mesh cages at $21 \pm 2^{\circ}$ for 3-4 d before initiation of each experiment. Control rats were maintained at that temperature while cold-acclimatized rats were moved to a cold room $\left(4 \pm 1^{\circ}\right)$, and housed at that temperature for $14 \mathrm{~d}$.

\section{Fasting experiments}

Rats were housed at $21 \pm 2^{\circ}$ and fed on a commercial pelleted diet (Ambar, Israel). According to the manufacturer, this diet (stock) contains $(\mathrm{g} / \mathrm{kg}): 500$ carbohydrate, 50 fat and 240 protein. Food and water were provided $a d$ lib. The animals were starved for 12 , 48 and $72 \mathrm{~h}$; fed rats were used as controls. The rats were anaesthetized by intraperitoneal administration of pentobarbital $(80 \mathrm{mg} / \mathrm{kg}$ body-weight); blood ( $3-5 \mathrm{ml})$ was drained from the vena cava with a heparinized syringe and then transferred to tubes placed in an ice-bath and later centrifuged. The plasma was stored frozen $\left(-20^{\circ}\right)$. Interscapular BAT was removed immediately, dissected free of contaminating and connective tissue, and frozen (within $10 \mathrm{~s}$ ) at the temperature of liquid nitrogen for subsequent analysis.

\section{Feeding experiments}

Male rats $(80 \mathrm{~g})$ were housed singly at $21 \pm 2^{\circ}$ or exposed to cold $\left(4 \pm 1^{\circ}\right)$ in a $12 \mathrm{~h}$ light-dark cycle. They were assigned at random into two groups for each temperature treatment. The groups were fed for $14 \mathrm{~d}$ on either diet $\mathrm{HF}$ containing $(\mathrm{g} / \mathrm{kg}): 390$ soya-bean oil, 200 casein, 310 maize starch, 10 vitamins, 40 minerals, 50 cellulose, or a diet $\mathrm{HC}$ containing $(\mathrm{g} / \mathrm{kg})$ : 590 maize starch, 200 casein, 110 soya-bean oil, 10 vitamins, 40 minerals, 50 cellulose. At the termination of the feeding experiments, the BAT was removed and treated as described previously for subsequent determination of PDH and GS activities and glycogen content. The plasma was used for glucose, pyruvate, lactate, triacylglycerol, cholesterol and insulin determinations.

\section{Analytical methods}

GS was assayed in BAT extracted as described elsewhere (Kochan et al. 1979; Madar et al. 1987). BAT $(80 \mathrm{mg} / \mathrm{ml})$ was homogenized in an extraction buffer containing: sodium fluoride $100 \mathrm{~mm}$, EDTA $10 \mathrm{~mm}$, benzamidine $1.0 \mathrm{~mm}$, Tris hydrochloride $50 \mathrm{~mm}(\mathrm{pH} \mathrm{7.8})$. The homogenates were centrifuged at $32800 \mathrm{~g}$ for $20 \mathrm{~min}$ at $4^{\circ}$. The supernatant fraction was used for GS determination. The reaction was initiated by addition of $60 \mu 1$ tissue extracts to $30 \mu \mathrm{l}$ of a reaction mixture (at $30^{\circ}$ ) containing $50 \mathrm{~mm}$-Tris hydrochloride (pH 7.8), $20 \mathrm{~mm}-\mathrm{EDTA}, 25 \mathrm{mM}-\mathrm{NaF}$. Glycogen $(10 \mathrm{~g} / \mathrm{l})$ and various concentrations of cold uridine diphosphate glucose (UDPG) and $\left[\mathrm{U}-{ }^{14} \mathrm{C}\right] \mathrm{UDPG}$ (specific activity $200 \mathrm{mCi} / \mathrm{mmol}$ ) were used for the kinetic experiments. Various concentrations of glucose-6-phosphate (G- 
6-P) at a fixed concentration of UDPG $(0.1 \mathrm{~mm})$ were also used for kinetic experiments. For feeding experiments, and for studying the effect of cold exposure, 0.1 and $10 \mathrm{mM}-\mathrm{G}-6-\mathrm{P}$ were used to determine GS enzyme activities $\left(G_{\mathrm{I}}\right.$, and $\mathrm{GS}_{\mathrm{H}}$ respectively) at $0.1 \mathrm{~mm}$-UDPG. The higher G-6-P concentration (10 mM) maximally activated GS at the subsaturating UDPG concentration of $0.1 \mathrm{~mm}$, while the lower G-6-P concentration $(0 \cdot 1 \mathrm{~mm})$ was chosen to activate the enzyme to around half maximal activation $\left(A_{0.5}\right)$ (Kochan et al. 1979). The reaction was terminated after $15 \mathrm{~min}$ by precipitating $75 \mu \mathrm{l}$ portions of the reaction mixture on $2 \times 20 \mathrm{~mm}$ pieces of filter paper dropped into cold ethanol $(660 \mathrm{ml} / 1)$. After $30 \mathrm{~min}$ the filter papers were washed twice for $20 \mathrm{~min}$ in cold ethanol $(660 \mathrm{ml} / 1)$, once for $5 \mathrm{~min}$ in acetone, dried, and placed in scintillation fluid for determination of radioactivity. Enzyme activity was expressed as nmol UDPG incorporated into glycogen $/ \mathrm{min}$ per $\mathrm{mg}$ protein. The assay was linear with respect to time for at least $20 \mathrm{~min}$.

PDH assay activity in BAT extract was determined as described previously (Madar et al. 1987), with the following modification: BAT $(5 \mathrm{mg})$ was homogenized (with a polytron) in $1.0 \mathrm{ml}$ extraction buffer (potassium hydrogen phosphate $0.05 \mathrm{M}$, dithiothreitol (DTT) $95 \mathrm{~mm}$, EDTA $1 \mathrm{~mm}, \mathrm{pH} 7 \cdot 4)$. The BAT extract was kept on ice. Portions $(100 \mu \mathrm{l})$ of the extract were pre-incubated for $10 \mathrm{~min}$ at $30^{\circ}$ in $50 \mu \mathrm{l}$ buffer extract and in $100 \mu \mathrm{l}$ of a mixture containing various concentrations of calcium chloride and magnesium chloride, $2 \mathrm{mM}$-DTT and $50 \mathrm{~mm}-\mathrm{KH}_{2} \mathrm{PO}_{4}$, at $\mathrm{pH} 7.4$ (total volume $150 \mu \mathrm{l}$ ), for the kinetic experiments (values not shown). For determination of the total PDH in the feeding experiments, activity was assayed at a high concentration of magnesium and calcium ions $\left(\mathrm{PDH}_{t}\right)$ as follows: the extracts were pre-incubated in the previously-described mixture with $50 \mu \mathrm{M}-\mathrm{Ca}^{2+}$ and $50 \mathrm{~mm}-\mathrm{Mg}^{2+}$. The reaction was started by the addition of a $25 \mu \mathrm{l}$ mixture of substrates and co-factors with the following composition (final concentrations): $\beta$-NAD $5 \mathrm{~mm}, \mathrm{KH}_{2} \mathrm{PO}_{4}$ $50 \mathrm{~mm}(\mathrm{pH} 7.4)$, sodium hydroxide $0.05 \mathrm{~mm}$, pyruvic acid $0.06 \mathrm{~mm}$, thiamine pyrophosphate $1.0 \mathrm{~mm}$, CoA $1.0 \mathrm{~mm}$, DTT $2.0 \mathrm{~mm},\left[1-{ }^{14} \mathrm{C}\right]$ pyruvic acid (specific activity $3 \mathrm{mCi} / \mathrm{mmol}$ ) $25 \mu \mathrm{l} / \mathrm{ml}$. The tubes were capped immediately with a rubber stopper, through which a plastic well containing a small roll of filter paper was suspended. After 20 min for liver extract and $15 \mathrm{~min}$ for muscle extract, the reaction was terminated by injection of $0.2 \mathrm{ml}$ $6 \mathrm{M}$-sulphuric acid through the rubber stopper onto the filter paper in the centre well. The filters were placed in scintillation fluid containing Triton for measurement of radioactivity. Results were calculated as nmol pyruvate oxidized/min per $\mathrm{mg}$ protein.

Glucose was determined by a glucose oxidase (EC 1.1.3.4) method using a glucose analyser (Beckman Bun 2). Insulin was assayed by a standard radioimmunoassay using polyethyleneglycol $(250 \mathrm{ml} / \mathrm{l})$ for separation of bound ligand from the free hormone. Plasma pyruvate and lactate were determined using a kit purchased from Sigma (Missouri, USA). Triacylglycerol and cholesterol were determined enzymically with a kit purchased from Trace Scientific (Australia).

Glycogen was assayed by treating the tissue for $20 \mathrm{~min}$ at $100^{\circ}$ with sodium sulphatesaturated potassium hydroxide $(300 \mathrm{~g} / 1)$. Glycogen was precipitated with ethanol (Dubois et al. 1956).

Protein was determined according to Bradford (1976), using a Bio-Rad commercial kit.

\section{Statistical analysis}

Values are expressed as means with their standard errors. A two-tailed Student's $t$ test and multiple-range analyses were used to determine statistical significance $(P<0.05)$. 


\section{RESULTS}

\section{Effect of fasting on GS activity in BAT}

Before determination of GS following starvation, the effect of G-6-P and UDPG concentrations on GS activity was measured. Fig. 1(A) shows the percentage GS activity expressed relative to activity $(\mathrm{I} \%)$ at $0.1 \mathrm{~mm}\left(\mathrm{GS}_{\mathrm{L}}\right)$ and at $10 \mathrm{~mm}\left(\mathrm{GS}_{\mathrm{H}}\right)$ of $\mathrm{G}-6-\mathrm{P}$ at different concentrations of UDPG. It is seen that $0 \cdot 1 \mathrm{~mm}-\mathrm{UDPG}$ represents a subsaturating concentration for GS activity. Fig. 1(B) shows the GS activity represented as a DPM of UDPG incorporated into glycogen (disintegrations/min) at different concentrations of G6-P. The G-6-P concentrations of $0.1 \mathrm{~mm}$ and $10 \mathrm{~mm}$ were chosen to achieve minimal (near the $A_{0.5}$ ) and maximal enzyme activation respectively (Fig. 1(B)). The subsequent experiments were conducted at $0 \cdot 1 \mathrm{~mm}-\mathrm{UDPG}$.

Fig. 2 demonstrates the effect of duration of starvation on GS activity in BAT. Following $12 \mathrm{~h}$ of fasting, $\mathrm{GS}_{\mathrm{L}}$ and $\mathrm{GS}_{\mathrm{H}}$ were significantly decreased. A similar effect was noted when the activity of GS was expressed as I\%. While $\mathrm{GS}_{\mathrm{H}}$ remained lower during the fasting period, $\mathrm{GS}_{\mathrm{L}}$ increased and reached the basal level after $72 \mathrm{~h}$ of fasting. $1 \%$ also increased after $12 \mathrm{~h}$ of fasting and reached a higher level after $72 \mathrm{~h}$ of starvation than in the fed state $(48$ v. $32 \mathrm{I} \%)$.

Changes in plasma variables following different durations of starvation were also measured (Table 1). Plasma glucose levels remained unchanged during the period of fasting, although after a $72 \mathrm{~h}$ fast the plasma glucose level decreased from 1460 (SE 379) to 1078 (SE 77) $\mathrm{g} / 1$ (not significantly different). Compared with the situation in the fed state, pyruvate levels were at a significantly lower $(P<0.05)$ level after starvation for $48 \mathrm{~h}(7.3$ (SE 0.8) v. 3.7 (SE 1.1) g/l) and for $72 \mathrm{~h} \mathrm{(7.3} \mathrm{(SE} \mathrm{0.8)} \mathrm{v.} 2.4$ (SE 0.7) g/l).

There was a marked decrease $(P<0.05)$ in glycogen content of BAT after a $12 \mathrm{~h}$ fast, although after a 48 or $72 \mathrm{~h}$ fast no significant differences were found between fed and starved rats, even though the glycogen content tended to be lower in fasted rats.

The body-weights of the experimental rats following the experimental period were not significantly different (values not shown). The body-weights ( $\mathrm{g}$ ) of the rats kept at $21^{\circ}$ were 167.9 (SE 2.84) and 165.5 (SE 5.79) when the rats were fed on diets HC or HF respectively, and 143.9 (SE 4.11) for diet HC and 147 (SE 2.63) for diet HF when they were exposed to the cold (not significantly different). The food intake was similar in all experimental groups, with a range of $11-14 \mathrm{~g} / \mathrm{d}$.

\section{Effect of cold exposure on $G S$ activity in $B A T$ of rats fed on diets $H C$ or $H F$}

Table 2 summarizes $\mathrm{GS}_{\mathrm{L}}$ and $\mathrm{GS}_{\mathrm{H}}$ activities in BAT of rats acclimatized to a low temperature and fed on different diets. Feeding the control rats diets $\mathrm{HC}$ or HF or stock diet did not have a significant effect on $\mathrm{GS}_{\mathrm{L}}$ or $\mathrm{GS}_{\mathrm{H}}$, but in cold-acclimatized rats fed on diet HF or stock diet, $\mathrm{GS}_{\mathrm{L}}$ in BAT was significantly lower $(P<0.05)$, than that in rats fed on diet $\mathrm{HC}$. Similar results were obtained for $\mathrm{GS}_{\mathrm{H}}$. $\mathrm{GS}_{\mathrm{L}}$ activity in acclimatized rats fed on either diet $\mathrm{HC}$ or diet HF was significantly higher $(P<0.05)$ than that in the control rats, the difference reaching five- and twofold with diets $\mathrm{HC}$ and $\mathrm{HF}$ respectively. The stock diet had the same effect on $\mathrm{GS}_{\mathrm{L}}$ in BAT of the control and the cold-acclimatized rats. The $\mathrm{GS}_{\mathrm{H}}$ activity in cold-acclimatized rats was higher than that in controls $(68.1$ (SE 2.77$) \mathrm{nmol} / \mathrm{min}$ per mg protein $v .39 \cdot 1$ (SE $5 \cdot 2) \mathrm{nmol} / \mathrm{min}$ per $\mathrm{mg}$ protein respectively) only in rats fed on diet $\mathrm{HC}$; diet $\mathrm{HF}$ or stock diet did not have a significant effect on $\mathrm{GS}_{\mathrm{H}}$.

The I \% in BAT of control and cold-acclimatized rats is shown in Fig. 3. Exposure of rats to low temperatures significantly $(P<0.05)$ increased the $1 \%$, independent of the diet source, and the cold-acclimatized rats fed on diet $\mathrm{HC}$ had a significantly $(P<0.05)$ higher I $\%$ than those fed on either diet HF or stock diet. 

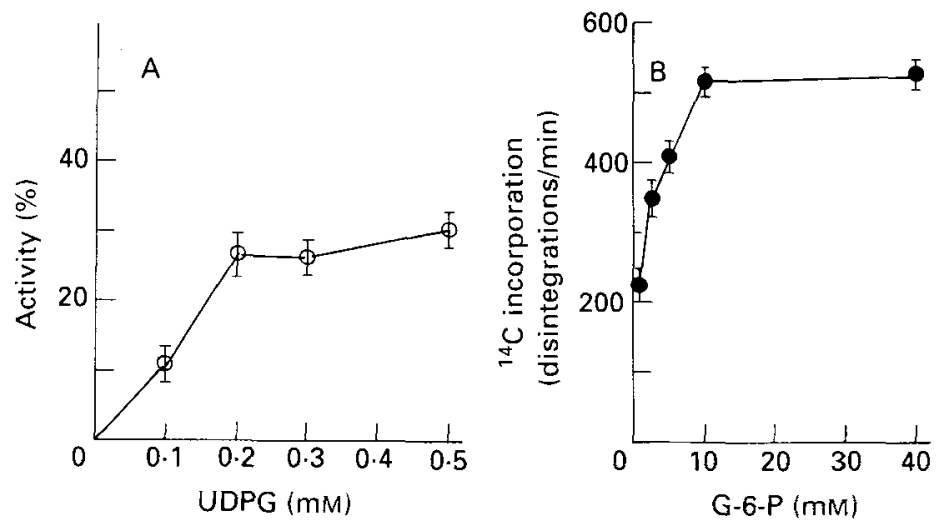

Fig. 1. (A) Effect of various concentrations of uridine diphosphate glucose (UDPG) on the percentage activity of glycogen synthase (EC 2.4.1.21; GS) calculated as the ratio, GS activity at $0 \cdot 1 \mathrm{~mm}$ : that at $10 \mathrm{~mm}$ glucose-6phosphate (G-6-P); (B) ${ }^{14} \mathrm{C}$-labelled UDPG incorporated into glycogen at different concentrations of G-6-P with a fixed concentration of cold UDPG (0.1 mM). Values are with their standard errors represented by vertica' bars for four experiments.

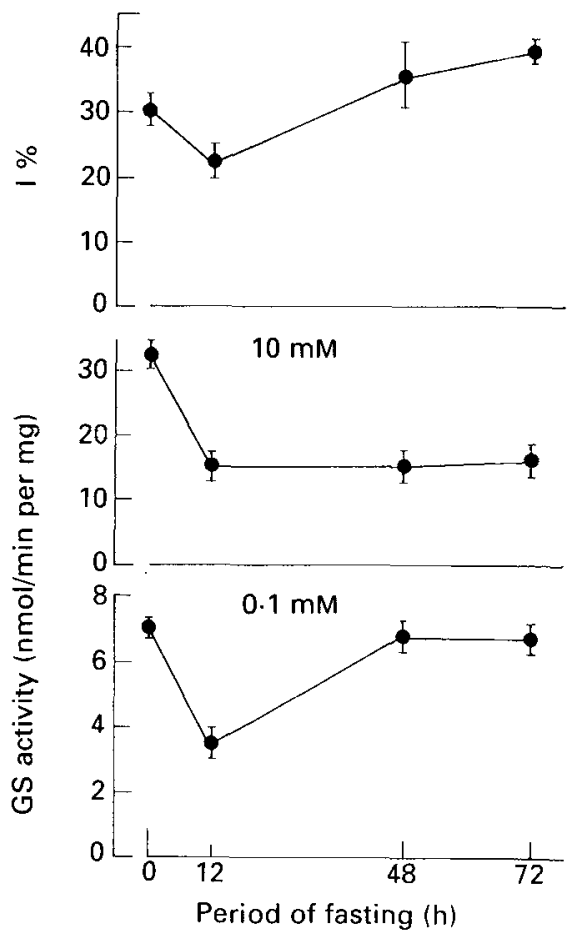

Fig. 2. Effect of fasting on glycogen synthase (EC 2.4.1.21; GS) activity in brown adipose tissue determined at a low concentration $(0.1 \mathrm{~mm})$ and high $(10 \mathrm{~mm})$ concentration of glucose- 6 -phosphate $(\mathrm{G}-6-\mathrm{P})$. I\% activity is the ratio, GS activity at $0.1 \mathrm{~mm}-\mathrm{G}-6-\mathrm{P}$ : that at $10 \mathrm{~mm}-\mathrm{G}-6-\mathrm{P}$. Values are means with their standard errors represented by vertical bars for seven rats.

In cold-acclimatized rats fed on diets $\mathrm{HF}$ and $\mathrm{HC}$, plasma triacylglycerol (409 (SE 49) $v$. 261 (SE 23) g/l) and cholesterol (1420 (SE 32) v. 1010 (SE 27) g/l) levels were significantly higher $(P<0.05)$ in rats fed on diet HF. Glycogen content $(\mathrm{g} / \mathrm{kg})$ in the BAT of rats fed on diet HC (151 (SE 7)) was significantly higher $(P<0 \cdot 05)$ than in those fed on diet HF (63 
Table 1. Metabolic variables of plasma and glycogen content of brown adipose tissue (BAT) after various periods of fasting*

(Values are means with their standard errors for fifteen rats)

\begin{tabular}{|c|c|c|c|c|c|c|c|c|}
\hline \multirow{2}{*}{$\begin{array}{c}\text { Duration of } \\
\text { fasting (h) }\end{array}$} & \multicolumn{2}{|c|}{ Glucose $(g / 1)$} & \multicolumn{2}{|c|}{ Pyruvate $(\mathrm{g} / 1)$} & \multicolumn{2}{|c|}{ Lactate $(\mathrm{g} / \mathrm{l})$} & \multicolumn{2}{|c|}{$\begin{array}{c}\text { BAT glycogen } \\
\text { (g/kg tissue) }\end{array}$} \\
\hline & Mean & $\mathrm{SE}$ & Mean & $\mathrm{SE}$ & Mean & $\mathrm{SE}$ & Mean & $\mathrm{SE}$ \\
\hline 0 & I $462^{a}$ & $37 y \cdot 0$ & $7 \cdot 3^{a}$ & 0.8 & $237 \cdot 0^{a}$ & $27 \cdot 7$ & $68^{a}$ & $1 \cdot 7$ \\
\hline 12 & $978^{a}$ & $57 \cdot 2$ & $7 \cdot 2^{a}$ & $2 \cdot 2$ & $249 \cdot 8^{a}$ & $22 \cdot 0$ & $34^{b}$ & 0.5 \\
\hline 48 & $1066^{\mathrm{a}}$ & $49 \cdot 9$ & $3.7^{b}$ & $1 \cdot 1$ & $201 \cdot 7^{a}$ & $10 \cdot 6$ & $50^{\mathrm{ab}}$ & $0 \cdot 4$ \\
\hline 72 & $1078^{a}$ & $77 \cdot 4$ & $2 \cdot 4^{17}$ & 0.7 & $175 \cdot 9^{\mathrm{a}}$ & $6 \cdot 1$ & $41^{\mathrm{ab}}$ & 0.6 \\
\hline
\end{tabular}

a,b. Within columns values with unlike superscript letters were significantly different $(P<0.05)$.

* For details of procedures, see pp. 96-97.

Table 2. Glycogen synthase (EC 2.4.1.21; GS) activity (nmol/min per mg protein) in response to cold exposure in brown adipose tissue of rats fed on a high-carbohydrate $(590 \mathrm{~g} / \mathrm{kg})$ or high-fat $(390 \mathrm{~g} / \mathrm{kg})$ diet $^{*}$

(Values are means with their standard errors for fifteen rats)

\begin{tabular}{|c|c|c|c|c|}
\hline \multirow[b]{3}{*}{ Treatment } & \multicolumn{4}{|c|}{$\begin{array}{l}\text { GS activity at G-6-P }(\mathrm{mm}) \\
\text { concentration of: }\end{array}$} \\
\hline & \multicolumn{2}{|c|}{$0 \cdot 1$} & \multicolumn{2}{|c|}{10} \\
\hline & Mean & $\mathrm{SE}$ & Mean & $\mathrm{SE}$ \\
\hline \multicolumn{5}{|l|}{ Control $\left(21 \pm 2^{\circ}\right)$} \\
\hline High-carbohydrate diet & $8 \cdot 5^{\mathrm{a}}$ & $1 \cdot 65$ & $39-1^{*}$ & $5 \cdot 20$ \\
\hline High-fat diet & $8 \cdot 8^{\mathrm{a}}$ & $1 \cdot 51$ & $38 \cdot 0^{\mathrm{a}}$ & $3 \cdot 75$ \\
\hline Stock diet & $7 \cdot 2^{\mathrm{a}}$ & $0 \cdot 85$ & $31 \cdot 3^{\mathrm{a}}$ & $7 \cdot 63$ \\
\hline \multicolumn{5}{|l|}{ Cold-acclimatized $\left(4 \pm 1^{\circ}\right)$} \\
\hline High-carbohydrate diet & $43 \cdot 2^{b}$ & 3.45 & $68 \cdot 1^{\mathrm{b}}$ & 2.77 \\
\hline High-fat diet & $19 \cdot 3^{b}$ & $2 \cdot 96$ & $44 \cdot 9^{\mathrm{b}}$ & $4 \cdot 65$ \\
\hline Stock diet & $10 \cdot 5^{\mathrm{ab}}$ & $0 \cdot 73$ & $21 \cdot 8^{\mathrm{a}}$ & $1 \cdot 25$ \\
\hline
\end{tabular}

G-6-P, glucose-6-phosphate

$\mathrm{a}, \mathrm{b}$, Values with unlike superscript letters were significantly different $(P<0.05)$ when control rats are compared with cold-acclimatized rats fed on the same diets.

* For details of procedures, see pp. 96-97.

(SE 3)). The other tested variables, glucose and lactate, remained unchanged, although insulin levels in rats fed on diet $\mathrm{HF}$ tended to be higher (23.1 (SE 9) $\mu \mathrm{U} / \mathrm{ml}$ ) than those in rats fed on diet $\mathrm{HC}$ (16.6 (SE 4) $\mu \mathrm{U} / \mathrm{ml}$ ).

The effect of cold exposure on PDH activity in rats fed on diets HF or HC is shown in Table 3. There was no significant difference in $\mathrm{PDH}$ at low $\mathrm{Mg}^{2+}$ and $\mathrm{Ca}^{2+}\left(\mathrm{PDH}_{\mathrm{a}}\right), \mathrm{PDH}_{\mathrm{t}}$ or $I \%$ between rats fed on either of these diets and maintained at $21 \pm 1^{\circ}$ or exposed to cold $\left(4 \pm 1^{\circ}\right)$. Rats fed on diet $\mathrm{HC}$ tended to have a higher I $\%$ than those fed on diet HF, but both $\mathrm{PDH}_{\mathrm{a}}$ and $\mathrm{PDH}_{\mathrm{t}}$ for cold-acclimatized rats were higher than values for the control group. $\mathrm{PDH}_{\mathrm{a}}$ increased significantly $(P<0.05)$, from 0.23 (SE 0.05) to 1.21 (SE 0.13) $\mathrm{nmol} / \mathrm{min}$ per $\mathrm{mg}$ and from 0.20 (SE 0.03) to 1.29 (SE 0.36) $\mathrm{nmol} / \mathrm{min}$ per $\mathrm{mg}$, following diets $\mathrm{HC}$ and $\mathrm{HF}$ respectively. Similar results were obtained with $\mathrm{PDH}_{\mathrm{t}}$. The $\mathrm{I} \%$ was significantly higher in cold-acclimatized rats than in control rats on both diets. 


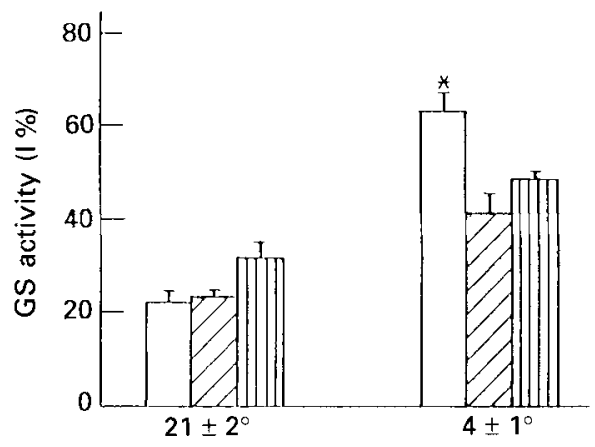

Fig. 3. Glycogen synthase ( $E C$ 2.4.1.21; GS) activity expressed as a percentage of that in brown adipose tissue of rats acclimatized to cold $\left(4 \pm 1^{\circ}\right)$ and fed on a high-carbohydrate $(\square)$, high-fat ( $\square$ ) or stock (四) diet. Values are means with their standard errors represented by vertical bars for twelve rats. I\% activity is the ratio, GS activity at $0.1 \mathrm{~mm}$-glucose-6-phosphate (G-6-P): that at $10 \mathrm{~mm}-\mathrm{G}-6-\mathrm{P}$. * Significantly higher than rats fed on highfat or stock diet $(P<0.05)$. Exposure of rats to low temperatures significantly increased the $1 \%$, independent of the diet source, $(P<0 \cdot 05)$.

Table 3. Pyruvate dehydrogenase (EC 1.2.2.2, 1.2.4.1; PDH) activity in response to cold exposure, in brown adipose tissue of rats fed on a high-carbohydrate or high-fat diet with $P D H$ measured at low $\left(P D H_{a}\right)$ and high $\left(P D H_{t}\right)$ concentrations of calcium and magnesium ions*

(Values are means with their standard errors for ten rats per treatment)

\begin{tabular}{|c|c|c|c|c|c|c|}
\hline \multirow[b]{3}{*}{ Treatment } & \multicolumn{6}{|c|}{ PDH activity (nmol/min per $\mathrm{mg}$ ) } \\
\hline & \multicolumn{2}{|c|}{$\mathrm{PDH}_{\mathrm{a}}$} & \multicolumn{2}{|c|}{$\mathrm{PDH}_{\mathrm{t}}$} & \multicolumn{2}{|c|}{$1 \% \dagger$} \\
\hline & Mean & $\mathrm{SE}$ & Mean & $\mathrm{SE}$ & Mean & SE \\
\hline \multicolumn{7}{|l|}{ Control $\left(21 \pm 2^{\circ}\right)$} \\
\hline High-carbohydrate & $0.23^{\mathrm{a}}$ & 0.03 & $1 \cdot 02^{\mathrm{a}}$ & 0.09 & $22 \cdot 5^{\mathrm{a}}$ & 1.77 \\
\hline High-fat & $0 \cdot 20^{\mathbf{a}}$ & 0.03 & $1 \cdot 18^{\mathrm{a}}$ & $0 \cdot 21$ & $16 \cdot 9^{\mathrm{a}}$ & $2 \cdot 24$ \\
\hline \multicolumn{7}{|c|}{ Cold-acclimatized $\left(4 \pm 1^{\circ}\right)$} \\
\hline High-carbohydrate & $1 \cdot 21^{\mathrm{b}}$ & $0 \cdot 13$ & $3 \cdot 53^{\mathrm{b}}$ & 0.66 & $342^{b}$ & $3 \cdot 50$ \\
\hline High-fat & $1 \cdot 29^{\mathrm{b}}$ & $0 \cdot 36$ & $4 \cdot 23^{\mathrm{b}}$ & 0.96 & $30 \cdot 5^{b}$ & $3 \cdot 15$ \\
\hline
\end{tabular}

There was no significant effect of diet in either control or cold-acclimatized rats. Control values were significantly different from cold-acclimatized values $(P<0.05)$.

a.b. Values with unlike superscript letters were significantly different $(P<0.05)$.

* For details of procedures, see pp. 96-97.

$\dagger$ Calculated as the ratio, $\mathrm{PDH}_{\mathrm{a}}: \mathbf{P D H}_{\mathbf{2}}$

Nevertheless, the rats fed on diet $\mathrm{HC}$ appeared to have higher $\mathrm{PDH}$ activity than those fed on diet HF (22.5 (SE 1.77) v. 16.9 (SE 2.24) nmol/min per $\mathrm{mg}$ in control rats, and 34.2 (SE 3.50$)$ v. $30.5(\mathrm{SE} 3 \cdot 15) \mathrm{nmol} / \mathrm{min}$ per $\mathrm{mg}$ in cold-acclimatized rats).

\section{DISCUSSION}

In the metabolism studies with BAT reported in the literature, emphasis was placed on lipogenesis (Sugden et al. 1982; Wearire \& Kanagasabai, 1982; Himns-Hagen, 1985; McCormack et al. 1986), consequently, only those enzymes involved in this pathway were investigated. It became apparent, however, that BAT plays different metabolic roles and that various metabolic pathways, and the enzymes involved in these pathways, may change 
with the physiological situation (starvation or refeeding), e.g. in fat, liver and muscle tissues (Nedergaard \& Lindberg, 1982). BAT has a high capacity for glucose utilization and, therefore, may play an important role in blood glucose control (Cooney \& Newsholme, 1982). It is known that, following a meal, much of the glucose is converted into glycogen (Hellertstein et al. 1986). GS is the enzyme that catalyses the incorporation of glucose into glycogen via UDPG. Thus, it was important to determine whether this metabolic pathway is active in BAT as it is in the liver or in white adipose tissue (Kochan et al. 1979; Mandarino et al. 1986). It has also been shown that BAT is sensitive to insulin. Thus, an impairment in the ability of BAT to respond to insulin, in which glucose is involved, indicates that this tissue plays a role in obesity or type II diabetes in which glucose tolerance is impaired (Young et al. 1984; Greco-Perotto et al. 1987). To the best of our knowledge, the present work is the first to demonstrate this type of GS activity in BAT in detail, although one short communication (Gibbins \& Denton, 1986) demonstrated GS activity in this tissue.

GS in BAT was found to have a higher affinity for the substrate (UDPG) than that in liver or white adipose tissue (values not shown). The UDPG concentration required for subsaturation was $0.1 \mathrm{~mm}$ (Fig. 1(A)), compared with $0.2 \mathrm{~mm}$ for liver and muscle, with a similar concentration of allosteric effector G-6-P (Madar, 1989). The GS activity of BAT, expressed as $\mathrm{nmol} / \mathrm{min}$ per $\mathrm{mg}$ protein, was higher than that of white adipose tissue (values not shown).

The optimal conditions for PDH activity, such as pyruvate ion concentration, were different for BAT and for liver and muscle tissue. While the pyruvic acid concentration used for the PDH assay in liver and muscle was $0.25 \mathrm{~mm}$ (Mandarino et al. 1986; Madar, 1989), that in BAT was $0.06 \mathrm{~mm}$. The concentrations of $\mathrm{Ca}^{2+}$ and $\mathrm{Mg}^{2+}$ for $\mathrm{PDH}_{\mathrm{a}}$ were similar for liver, muscle and BAT, whereas those for $\mathrm{PDH}_{\mathrm{t}}$ determination in BAT were lower (see p. 97) than those in muscle and liver ( 500 v. $50 \mu \mathrm{M} \mathrm{Ca}^{2+}$ and 50 v. $500 \mathrm{mM} \mathrm{Mg}{ }^{2+}$ ). These results indicate that although the activity principle of both enzymes is the same, the optimal concentration of reaction components in various tissues differs. This could indicate that these enzymes are more sensitive to physiological modulators in BAT than in the other tissues, but this characteristic requires further study for determination of its metabolic role.

Prolonged starvation reduced the $\mathrm{GS}_{\mathrm{H}}$ activity from 30 (SE 1.5) to 15 (SE 2.5) nmol/min per mg after $72 \mathrm{~h}$ of fasting, but the $\mathrm{GS}_{\mathrm{L}}$ remained unchanged (Fig. 2), although there was a transient decrease after $12 \mathrm{~h}$ of fasting. No significant changes were noted in $\mathrm{I} \%$. The change in GS activity was consistent with the change in glycogen content in the BAT (Table 1). Glycogen content decreased after $12 \mathrm{~h}$ of fasting, as did GS activity. After 48 and $72 \mathrm{~h}$ of fasting glycogen increased, but not to the same extent as in the fed situation. The present results are inconsistent with those found in muscle and liver tissue (Kaslow \& Eishner, 1984; Madar, 1989). This may indicate that the same enzymes act differently in different tissues, according to their needs. Although current findings relating to the role of GS in BAT are sparse, we believe this enzyme exists in an active form in BAT and is involved in the synthesis of glycogen in this tissue.

Our findings are consistent with previously published results (Gibbins \& Denton, 1986). However, the latter study was done with female rats and $\mathrm{GS}_{\mathrm{L}}$ was determined in the absence of G-6-P. GS activity in the present study not only increased after cold acclimatization (Table 2 and Fig. 3), but the elevation was more marked after feeding diet $\mathrm{HC}$ than after diet HF or stock diet. When the results were expressed as I\%, the increase in GS activity following diet $\mathrm{HC}$ was even more dramatic. This enabled the BAT to take up the glucose from the blood and utilize it directly for thermogenesis, or to store it as glycogen for later use. The increase in GS activity also enabled the tissue to respond immediately to cold stress. In our opinion glycogen metabolism is an important factor in rat BAT, contributing 
to the control of blood glucose. Also, GS may play a major role in glucose metabolism in BAT, as it does in muscle or liver tissue. However, this is not in accord with previous studies on rat BAT metabolism (Cawthorne, 1989). According to the results of Gibbins \& Denton (1986), GS appears to be under hormonal regulation in BAT, mainly by insulin and catecholamines (Gibbins \& Denton, 1986; Howland \& Bond, 1987). However, the present results show that feeding diet HF decreased GS activity, whereas the insulin levels were higher with this diet than with diet HC. This indicates that BAT may develop insulin resistance when rats are fed on a high-fat diet. It should be noted that Nedergaard \& Lindberg (1982) suggested that glycogen metabolism does not play a significant role in BAT. The contribution of insulin to glycogen synthesis in BAT requires further clarification.

The present findings also point to the importance of the type of diet in regulating GS activity. In cold-acclimatized rats diet $\mathrm{HC}$ significantly $(P<0.05)$ increased GS activity compared with diet HF or stock diet (Table 2). This observation adds to the evidence linking GS to the metabolic activity of BAT. GS activity was inhibited in BAT after the rats were exposed to cold, consequently the glycogen synthesis pathway will be inhibited. Glucose in this state will serve as a possible fuel for thermogenesis. However, further elucidation of this point is still required.

Our results indicate that an excess of glucose derived from diet $\mathrm{HC}$ and not oxidized for heat production, could be converted into glycogen in BAT. This could explain why GS appears to be activated in BAT. Consequently, the plasma glucose levels remain unchanged. Nevertheless, the relevance of GS activity in thermogenesis needs to be investigated. Serra et al. (1987) reported that not only were the enzymes which are intimately involved in the thermogenic function of BAT activated, but also the enzymes involved in amino acid metabolism. The activity of the latter enzymes was much higher than that found in white adipose tissue, results which are similar to those reported for GS.

The effect of cold acclimatization and diet on PDH activity found here confirmed earlier observations (McCormack et al. 1986). $\mathrm{PDH}$ in the active form $\left(\mathrm{PDH}_{\mathrm{a}}\right)$ and $\mathrm{I} \%$ were higher in BAT from cold-acclimatized rats (diets $\mathrm{HC}$ or HF) than from control rats, regardless of diet (Table 3 ).

In summary, GS activity was found in BAT. This enzyme was found to have a high affinity for UDPG. Cold exposure increases the activity of this enzyme, as has been found for other enzymes described. Furthermore, rats exposed to cold and fed on diet $\mathrm{HC}$ exhibited increased GS activity, accompanied by a large amount of glycogen. This indicates that GS may play a role in controlling blood glucose and also be an important factor in thermogenesis.

\section{REFERENCES}

Bradford, M. M. (1976). A rapid and sensitive method for the quantitation of microgram quantities of protein utilizing the principle of protein-dye binding. Analytical Biochemistry 72, 248-254.

Cawthorne, M. A. (1989). Does brown adipose tissue have a role to play in glucose homeostasis? Proceedings of the Nutrition Society 48, 207-214.

Cooney, G. J. \& Newsholme, E. A. (1982). The maximum capacity of glycolysis in brown adipose tissue and its relationship to control of the blood glucose concentration. FEBS Letters 148, 198-200.

Cooney, G. J. \& Newsholme, E. A. (1984). Does brown adipose tissue have a metabolic role in the rat? Trends in Biochemical Sciences 9, 303-305.

Cooney, G. J., Taegtmeyer, H. \& Newsholme, E. A. (1981). Tricarboxylic acid cycle flux and enzyme activities in the isolated working rat heart. Biochemical Journal 200, 701-703.

Denton, R. M., McCormack, J. G. \& Marshall, S. E. (1984). Persistence of the effect of insulin on pyruvate dehydrogenase activity in rat white and brown adipose tissue during the preparation and subsequent incubation of mitochondria. Biochemical Joumal 221, 441-452.

Dubois, M., Gilles, K. A., Hamilton, J. K., Rebers, P. A. \& Smith, F. (1956). Colorimetric method for determination of sugars and related substances. Analytical Chemistry 28, 350-356. 
Ferre, P., Burnol, A. F., Leturque, A., Terretaz, J., Penicaud, L., Jeanrenaud, B. \& Girard, J. (1986). Glucose utilization in vivo and insulin-sensitivity in brown adipose tissue in various physiological and pathological conditions. Biochemical Journal 233, 249-252.

Gibbins, J. M. \& Denton, R. M. (1986). Glycogen metabolism in rat interscapular brown adipose tissue. Biochemical Society Transactions 14, 278-279.

Greco-Perotto, R., Assimacopoulos-Jeannet, F. \& Jeanrenaud, B. (1987). Insulin modifies the properties in rat brown adipose tissue. Biochemical Journal 247, 63-68.

Hellertstein, M. K., Greenblatt, D. J. \& Munro, H. (1986). Glycoconjugates as noninvasive probes of intrahepatic metabolism: Pathways of glucose entry into compartmentalized hepatic UDP-glucose pools during glycogen accumulation. Proceedings of the National Academy of Sciences U.S.A. 83, 7044-7048.

Himns-Hagen, J. (1985). Brown adipose tissue metabolism and thermogenesis. Annual Review of Nutrition 5, 69-94.

Howland, R. J. \& Bond, K. D. (1987). Cold-acclimation increases insulin sensitivity of brown adipocytes. Hormone and Metabolic Research 19, 503-504.

Isler, D., Hill, H. P. \& Meier, M. K. (1987). Glucose metabolism in isolated brown adipocytes under $\beta$-adrenergic stimulation. Quantitative contribution of glucose to total thermogenesis. Biochemical Journal 245, 789-793.

Kaslow, H. R. \& Eishner, H. D. (1984). Fasting and diabetes alter adipose tissue glycogen synthase. American Journal of Physiology 247, E581-E585.

Kochan, R. G., Lamb, D. R., Lutz, S. A., Perrill, C. V., Reimann, E. M. \& Schlender, K. K. (1979). Glycogen synthase activation in human skeletal muscle: effects of diet and exercise. American Journal of Physiology 236, E660-E666.

McCormack, J. G. (1982). The regulation of fatty acid synthesis in brown adipose tissue by insulin. Progress in Lipids Research 21, 195-223.

McCormack, J. G., Gibbins, J. M. \& Denton, R. M. (1986). Lipogenesis in brown adipose tissue and its regulation. Biochemical Society Transactions 14, 227-229.

Madar, Z. (1989). Pyruvate dehydrogenase and glycogen synthase activity at transition from fasted and fed state. Biochemical Medicine and Metabolic Biology 41, 93-104.

Madar, Z., Bell, J. M. \& Mandarino, L. J. (1987). Glycogen synthase kinetics in isolated human adipocytes: an in vitro model for the effect of insulin on glycogen synthase. Biochemical Medicine and Metabolic Biology 38, 265-271.

Mandarino, L. J., Madar, Z., Kolterman, O. G., Bell, H. M. \& Olefsky, J. M. (1986). Adipocytes, glucogen synthase and pyruvate dehydrogenase in obese and type II diabetic subjects. American Journal of Physiology 251, E489-E496.

Nedergaard, J. \& Lindberg, O. (1982). The brown fat-cell, review. International Review of Cytology 74, $187-286$.

Serra, F., Bonet, L. \& Palou, A. (1987). Amino-acid enzyme activities in brown and white adipose tissues and in the liver of cafeteria rats. Effects of 24 hours starving. Archives Internationales de Physiologie et de Biochimie 95, 263-268.

Sugden, M. C., Watts, D. I., Marshall, C. E. \& McCormack, J. G. (1982). Brown-adipose-tissue lipogenesis in starvation: effects of insulin and (-) hydroxycitrate. Bioscience Reports 2, 289-297.

Trayhurn, P. (1979). Fatty acid synthesis in vivo in brown adipose tissue, liver and white adipose tissue of the coldacclimated rat. FEBS Letters 104, 13-16.

Wearire, P. J. \& Kanagasabai, T. F. (1982). Effect of high-carbohydrate diets on lipogenesis in rat interscapular brown adipose tissue. Biochemical Journal 206, 667 669.

Young, P., Cawthorne, M. A., Levy, A. L. \& Wilson, K. (1984). Reduced maximum capacity of glycolysis in brown adipose tissue of genetically obese, diabetic $(\mathrm{db} / \mathrm{db})$ mice and its restoration following treatment with a thermogenic $\beta$-adrenoceptor agonist. FEBS Letters 176, 16-20. 